\title{
A DECISION-MAKING MODEL FOR CONTROLLING LOGISTICS COSTS
}

\author{
Sebastjan Škerlič, Robert Muha, Klavdij Logožar
}

Original scientific paper

A lack of understanding of logistics costs, particularly in terms of their integrity and interdependence, allows for the interests of individual departments within a company, which are not always in line with the common interests of the business process of the company, to take precedence over necessary logistics cost planning. In order to address this problem, we have developed a model that takes into account all the logistical costs within a company and represents an important decision-making tool that can be used by employees at different levels of the organization, covering different business functions. We have tested the model on a specific product in a company that operates in the automotive industry and determined that the model enables us to have greater control over logistics costs and improves the quality of information on logistics costs.

Keywords: decision making; knowledge transfer; logistics cost; logistics cost models

Model odlučivanja za kontrolu logističkih troškova

Izvorni znanstveni članak Nedostatno poznavanje logističkih troškova, posebice u pogledu njihove cjelovitosti i međusobne ovisnosti, vodi do toga da na štetu nužnog planiranja logističkih troškova prevagnu interesi pojedinačnih službi unutar poduzeća koji nisu u skladu s općim interesima poslovnog procesa poduzeća. Suočeni s tim problemom izradili smo model koji uzima u obzir sve logističke troškove u jednom poduzeću i koji predstavlja važno oruđe odlučivanja za zaposlenike svih razina i funkcija. Taj model smo testirali na specifičnom proizvodu jednog poduzeća iz automobilske industrije i ustanovili da nam on omogućava veću kontrolu nad logističkim troškovima i poboljšava kvalitetu informacija o logističkim troškovima.

Ključne riječi: logistički troškovi; logistički troškovni modeli; odlučivanje; prijenos znanja

\section{Introduction}

Companies that distribute the majority of their products outside their local markets, often struggle to meet customer expectations with low logistics costs. Different departments within a company often have different perceptions in regard to which elements in the business process of purchasing, selling and distributing goods should be deemed the most important [11]. When planning the quantity of incoming raw materials, the focus of the purchasing department is to purchase large quantities of goods with shorter payment terms, because this is the easiest way to obtain quantity discounts. This impinges on the logistics department because of the additional warehousing and the costs of capital in stocks. On the other hand, a fully loaded vehicle is preferred by the transport service, as this ensures the best price-toquantity of transported goods ratio.

In the distribution of goods to the final customer, the sales department strives to meet customer demands with smaller batches in terms of quantity, longer payment terms and the assurance of adequate safety stock levels.

All of the above represents an additional problem for the transport service, because of the necessity to organize transport at the lowest possible cost, while at the same time taking into account the "just in time" principle. Large stock quantities and longer payment terms are a problem for the logistics and financial departments, as they can lead to the deterioration of the company's liquidity and increase the burden on the company's storage capacities.

A lack of understanding of logistics costs exposes the conflicts of interests within individual departments of a company, which are not always in line with the common interests of the business process of the company.

Research is therefore focused on developing a single criterion for controlling logistics costs within a company, which could represent an important decision-making tool that could be utilised by employees at different levels of the organisation (corporate executives, middle management, operational staff) and by each individual department within the company (sales, purchasing, logistics, production, marketing, etc.). The results of the tests performed on a specific product showed that the proposed Systematic Logistics Decision-Making Model (SLDM) offers insight into the impact of the different levels of decision making on the amount of logistics costs. It allows us to compare results in real time on the basis of input data changes, entered into the model by each individual department within the company. The model is formulated in such a way that it allows every company employee to use it with ease. This allows employees lacking adequate knowledge of logistics, decisions relating to which affect the level of logistics costs, to familiarize themselves with the logistics process.

The tests were performed on a specific product in a manufacturing company, hinge G9. The objective of the tests was to determine:

- the applicability of the model in practice,

- whether the model can provide us with information about logistics costs that is of better quality than the information that is currently available to us.

The paper is structured as follows: in Section 2 we provide an overview of the literature in the field of logistics cost models. This is followed by an analysis of the applicability of logistics models in terms of the connectedness of the different levels of decision making, the methods used to analyse logistics costs and the transfer of knowledge. In Section 5, we present the test of the Systematic Logistics Decision-Making Model (SLDM) on a specific product made by a manufacturing company in the automotive industry. We conclude the paper with an analysis of the results obtained the advantages of the model and its contribution to theory and 
practice. In addition, we identify the model's limitations and provide some suggestions for further research.

\section{Review of the literature in the field of logistics cost models}

The theoretical structure of logistics models is designed using different cost and mathematical methods, which is why the designs vary in complexity, purpose, and type of use. Blumenfeld et al. [8] conducted a study that identified the optimal strategies of delivering goods on a freight network. They analysed the relationship between transport, warehousing, and production set-up costs in order to minimize the total costs. A decomposition method was presented to solve problems with a few origins and shipment sizes. A similar study was published by Burns et al. [12], which explored the problem of reducing the total costs of inventory and transport from each supplier to a larger number of customers using the structure of the economic order quantity (EOQ) model. They derived formulas for the inventory and transport costs and determined the optimal trade-off between these costs. Blumenfeld et al. [9] continued their scientific research in the case of General Motors. They examined the delivery of goods from the suppliers to the production facilities with the goal of reducing total logistics costs, which included transport and warehousing costs. The correlation between the costs of inventory and transport costs was also examined by Speranza and Ukovich [24] with the purpose of optimizing costs in the supply of various products.

The Speranza/Ukovich study was upgraded by Bartazzi et al. [5] by seeking cost solutions in the supply of products from one source to a number of different destinations, especially when given a fixed set of possible delivery frequencies. In this case, the objective is also to reduce the total cost of inventory and transport. The authors presented different heuristic algorithms and tested them on a set of randomly generated problem instances.

Bertazzi and Speranza [6] have studied scientific papers that present models for the minimization of the sum of inventory and transport costs in logistics networks. The purpose of their work is to set guidelines for the interpretation of different logistics models over time.

Zhao et al. [32] addressed the problem of determining the optimal ordering quantity and frequency for a supplier-retailer logistics system in which the transport cost as well as the multiple uses of vehicles are considered. Based on the traditional economic order quantity formula, a modified EOQ model is set up and an algorithm for the model is presented. The purpose of the model is to reduce production, inventory, and transport costs.

Berman and Wang [4] also built a model that represents a good solution and can serve as a guideline for the future planning and implementation of an appropriate distribution network, where the total costs of transport and inventories are the lowest. Madadi et al. [19] formulated a multi-level inventory model that includes transport costs for planning the replenishment of a single commodity. They extend the traditional EOQ model in order to minimize the total inventory cost while considering a discrete transport cost, which determines the optimal strategy of the warehouse to decide how often to place orders. They also developed a collective form of ordering by retailers and a plan to minimize the inventory cost of the retailers and the warehouse jointly.

Wang and Cheng [30] produced a logistics scheduling model in which the objective is to minimize the sum of work-in-process inventory costs and transport costs, which includes both supply and delivery costs. They proved that if work orders from a supplier, manufacturer, and buyer require the same amount of time to be processed, the costs of inventory and transport can be optimized on all levels. Ali and O'Connor [1] developed a model that is designed for effective operational planning in the distribution system and determines the number of trucks that are deployed, the placement of the trucks, and inventories over time. The model optimizes the total fixed cost of transporting a product and the total inventory carrying costs at both echelons. The inventory costs in the model take into account both the cost of the item held in inventory and the granularity of the time period over which the inventory is held. The developed heuristic procedure addresses the trade-off between the fixed cost of transport and inventory carrying cost to determine deployments to each demand point, thereby reducing the number of variables in the model.

From the point of view of warehouse process management, Guerriero et al. [15] developed a mathematical model that stresses the problem of the allocation of products in a multi-layer warehouse where there are restrictions on combining different classes of products. The strategy used to allocate the products (Products Allocation Problem) influences almost all warehouse performance (e.g., order picking time and cost, productivity, inventory accuracy, and space requirement for each product), and strongly depends on its layout.

Thus, a lot of restrictions that should occur in real contexts need to be taken into account: the pallets of a given product have to be allocated in slots close to each other; the most requested products have to be allocated in slots close to the input/output (I/O) doors of the warehouse in order to reduce the picking time and the cost of other logistics operations.

Strack and Pochet [27] introduce a model that combines multiple tactical phases in the process of logistics decision making: the completion of decisions in inventory management, the allocation of products in the warehousing system of a company, and the transfer of products to warehouse locations in the warehouse management process. The merging of the decisionmaking phases makes it possible to reduce warehousing and inventory costs by optimizing the quantity of each product in the warehouse. The system is designed in such a way that it enables the process of supplying the customers to run uninterrupted, while at the same time the warehouse zone is filling up evenly with the necessary inventory through simultaneous orders to suppliers. This model enables the optimization of external supplies with the level of safety stock required to ensure proper customer service. This method of warehouse and inventory management reduces the total operational costs while satisfying customer needs. Operational costs include purchasing costs, the costs of holding goods in the 
warehouse, and stock-out costs - which are incurred when it is not possible to meet customer demand (cost of lost sales).

Sajadieh et al. [23] used the model developed to show the importance of coordination and cooperation between the seller and the buyer in a two-stage supply chain. This relationship allows for the costs of inventory and warehousing to be kept at a minimum. Tancrez et al. [28] developed a model that combines the decisions regarding the choice of location for the distribution centres, the distribution of goods flows, and the size of individual shipments. The objective of the model is the choice of appropriate distribution centres that effectively connect the location of production facilities to the locations of final customers. The model focuses on the optimization of inventory and transport costs. A conflict arises between the two cost components, because if the goods are supplied directly from the factory to the final customers, the costs of inventory and warehousing are reduced, but transport costs are higher. The opposite scenario occurs when using distribution centres to supply customers that allow for the optimal use of transport capacities, but also cause an increase in the cost of inventories and warehousing. The purpose of the model is to find solutions that enable the optimal level of supply and the creation of an efficient supply chain network.

Lau and Nakandala [18] developed a mathematical model that supports a set of rules for decision-making to assist wholesalers in determining whether it is more cost effective to tranship urgent, outstanding retailer orders from other wholesalers at a higher purchase cost, or to order from their suppliers. By considering the uncertainty in demand, it models the total cost encountered by wholesalers, including purchasing, backordering, and holding costs in the inventory replenishment process.

Bošnjaković [10] build the multicriteria inventory model for optimizing costs related to spare parts. The proposed criteria for optimization are: value-usage, criticality and frequency of demand. It is based on ranking and classifying the spare parts in groups according to similar attributes. Each group of spares, depending on attributes of the spares that belong to it, joins the appropriate inventory policy model and forecasting demand model.

Some logistics models use a simpler approach. Pettersson and Segerstedt [21] developed a model for measuring costs in the supply chain, where logistics costs play an important role. They conducted a study in order to determine how 30 different companies in ten different industry sectors measure their supply chain costs and compared the results with the model they developed.

There is also a strategic profit model $[25,26]$, which shows how managing the assets and the margin affects the return on assets and net assets. Logistics activities play an important role in the model, which are present in the company's assets, which is why the model is also useful for management in determining the role of logistics in the corporate success of the company. The model focuses specifically on financial flows and identifies cash flow as the basis for a balance between the company and its environment. The model is specific in the calculation of return on net assets, where all logistics costs are taken into account (transport costs, warehousing costs, administrative costs, inventories, etc.), as well as the interactions between them. The model emphasizes the importance of optimizing inventories. A significant reduction in stock quantities, without taking into account the effects of other logistics costs, can significantly increase the total logistics costs. It is therefore important for the model to focus on efficiency and effectiveness in achieving the goals of the company as a system, rather than on optimizing individual logistics subsystems (e.g. transport, warehousing, etc.). Robinson [22] developed a 'Landed Cost Model,' which compares and evaluates geographic regions based on the different costs: labour, logistics, inventory, and duties. In order to ensure the efficient flow of goods in the process of transport, Chow [13] drew up a model for the analysis of transport destinations, which includes various types of transport (air, sea, road). Based on a cost simulation, an annual comparison between the destinations was made. The cost analysis does not only take into account the price of transport services, but also the costs of inventory, warehousing, handling, and order processing. The simulations show how improvements in transit times and in the reliability of transport reduce total logistics costs, and, based on this, how a specific transport route is more competitive compared to another route.

\section{Evaluating the logistics cost models and their usability for the company's logistics process}

A well-designed decision support system will help decision makers to extract useful information from raw data, documents and personal knowledge with the objective of identifying and solving problems and making decisions [16]. Logistics cost models as components of decision-making support systems are built using different cost and mathematical methods, which is why they vary in complexity, purpose and usability. Regardless of that, our analysis of the literature focuses on three elements that define their usability: the level of decision making, the logistics costs examined and the transfer of knowledge.

\subsection{The impact of the participation of different decision- making levels on logistics costs reduction}

The scope of logistics optimization in companies and organizations has expanded to address strategic, tactical and operational decision making [3]. The characteristics of different levels of decision making derive from studies of space and time (the horizon and the period of decision making) and hierarchical analyses [14], which is why it is important to determine how many of these characteristics can be found in each model. In the literature reviewed, the authors developed logistics cost models that address areas that are strategic in nature, because of their study subject: building an optimal strategy of goods delivery, the implementation of a proper distribution network, determining the optimal quantity of products ordered, the optimization of planning in the distribution system, the analysis of transport destinations, coordinating the logistics network and the distribution of trade flows, building a system for selecting distribution centre locations, coordinating processes in a two-stage and three- 
stage supply chain, inventory management and building a system for the allocation of products in the warehouse.

The areas studied require us to determine long-term goals and measures that are defined by strategic and, to a lesser extent, tactical, decisions. Such decisions are largely made by top management, which is why we have to ask ourselves how a certain cost model could also offer support to other employees in a company. Employees at lower levels make various operational decisions on a daily basis that must also be supported by the right decisionmaking tools. Efficient logistics costs management is therefore only possible if employees on different hierarchical levels are involved in the process (executives, middle management, operational staff), as well as employees who perform different business functions (sales, purchasing, logistics, production, etc.). A model that is capable of combining individually tailored solutions for the reduction of logistics costs into a single criterion for strategic, tactical and operational decision making is not merely useful in general, but also systematically addresses all the logistical costs of a company.

\subsection{The various methods used by different models to address logistics costs}

The applicability of cost models can be analysed based on which and how many of the logistics costs can be examined at the same time. In the available literature, the authors develop logistic models with the goal of reducing total logistics costs, which include the following relationships: the link between the cost of inventory and transport costs, the correlation between the cost of inventory and warehousing costs, an analysis of the relationship between transport, warehousing and production set-up costs, the reduction of the total cost of inventories and transport with the use of the EOQ model structure, the management of transport costs in the selection of the optimal order quantity and the number of vehicles, the minimization of the sum of work-in-process inventory costs and transport costs, which includes both supply and delivery costs, the reduction of warehouse space costs, the optimization of warehousing and inventory costs, the reduction of operating costs (cost of purchasing, cost of holding goods in storage and stock-out costs, which are incurred when it is not possible to meet customer demand (cost of lost sales) and the impact of reducing the amount of stock on the level of logistics costs.

It can be concluded that the models are not targeted at all the logistics costs, but on the individual relationship between the costs of transport, warehousing and inventory. Scientific studies focus on these costs, because they represent the majority in the structure of logistics costs. Other logistics costs are discussed to a lesser extent, due to the fact that different authors classify them differently and group them with the three most commonly studied types of logistics costs. In addition, logistics costs and the relations between them are difficult to measure and even more difficult to be made into a cost model, because they can be affected by so many exogenous factors and due to the fact that many of them are nonstationary [29]. However, this should not discourage us from establishing a system that could be used to evaluate and measure all logistics costs and attempt to effectively translate the changes in the environment into a cost model. This can be achieved if the logistics models are developed in a way that allows them to be upgraded with new cost variables.

\subsection{The transfer of knowledge on logistics costs}

The transfer of knowledge is defined as "the process through which one unit is affected by the experience of another" [2], because knowledge never exists independent of relationships with an event, an idea, or another person. Knowledge is created in relationships, inside thinking, reflecting human beings [31]. However, individuals or functional departments have very limited knowledge. Their partial knowledge from different sources therefore needs to be reorganized and combined into an integrated knowledge model for conceptualizing the target management problem [20].

Based on the literature reviewed, we can see that the development of logistics cost models has reached a stage where they can no longer be considered user-friendly to potential users in companies. The logistics cost models examined in this paper offer important mathematics solutions in terms of solving complex and complicated logistical problems. However, the knowledge transferred by the development of various heuristic approaches and algorithmic structured models is only available to a small circle of experts. Models that are structured in this way do not allow for the participation of those who make an important contribution to the intellectual logistics capital of the company by transferring their knowledge and experience. Each process is therefore not capable of establishing useful knowledge and thus organizing the basic principles of knowledge creation that will be useful to the company in the long run [7]. Logistics costs are present across different business functions of the company, so it is important that the model allow for the creation of knowledge that will be accessible to a wider circle of employees who will create new value through their own experiences and through the experiences of others.

\section{Methods}

The proposed model was tested in a manufacturing company with 350 million euros in annual revenue and 40 years of experience in the international automotive industry, which is one of the largest industrial enterprises in Slovenia. The company produces more than 50 million automotive components every year and delivers to more than 160 locations every day. The product hinge G9 falls under the product category of chassis and car-body parts, which the company produces for some of the leading automotive manufacturers in the world: Peugeot \& Citroen (PSA Corporation), BMW, Audi and Mercedes. Of the 3,8 million hinges required by the world's largest car manufacturers, the company holds a $10,8 \%$ share.

In order to test the model on the product hinge G9, we prepared Tab. 1, which is required for the entry of the data on individual logistics costs incurred by the company in connection to this product. The letter $M$ is used to 
denote a piece of data that was entered by the company, which is required for the purpose of testing the proposed model. The letter $\mathrm{C}$ is used to denote the actual cost incurred by the company for the product and is required for a final comparison. The right-hand column contains the abbreviations of the formulas that will be used for testing the proposed (SLDM) model. The bottom of the table is reserved for data concerning other logistics costs that are not evaluated separately in the model. These data have been provided by the controlling and production technology departments.

Table 1 Data required for testing the proposed model on the product hinge G9

\begin{tabular}{|c|c|c|c|}
\hline & & Data entry & SLDM \\
\hline $\mathrm{M}$ & Product & Hinges G9 & $P$ \\
\hline $\mathrm{M}$ & Product price $€$ & 2,277 & $P p$ \\
\hline $\mathrm{M}$ & Net weight of product $(\mathrm{kg})$ & 0,632 & $N w P$ \\
\hline $\mathrm{M}$ & Product life cycle (years) & 6 & Plc \\
\hline $\mathrm{M}$ & Weight of packaging (kg) & 36 & $W p$ \\
\hline $\mathrm{M}$ & Number of pieces in packaging unit & 196 & $\mathrm{~Np}$ \\
\hline $\mathrm{M}$ & Packing dimensions $(\mathrm{m})$ & $0,78 \times 0,57 \times 0,478$ & $P d$ \\
\hline \multicolumn{4}{|c|}{ PACKAGING } \\
\hline $\mathrm{M}$ & Packaging cost per pallet $€$ (material) & 1,700 & $P c M$ \\
\hline $\mathrm{C}$ & Non returnable packaging cost per pcs $€$ & 0,011 & $N r p c / p$ \\
\hline $\mathrm{M}$ & Num. of returnable packaging in circulation & 0 & Nurp \\
\hline $\mathrm{M}$ & Packaging stock & 5 & $P s$ \\
\hline $\mathrm{M}$ & Packaging unit cost $€$ & 200,00 & $P u c$ \\
\hline $\mathrm{M}$ & Number of pcs in the product life cycle & 0 & $\mathrm{NpPlc}$ \\
\hline $\mathrm{M}$ & Value of returnable packaging & 0,000 & $V r p$ \\
\hline $\mathrm{C}$ & Returnable packaging cost per pcs $€$ & 0,000 & $R p C p$ \\
\hline \multicolumn{4}{|c|}{ TRANSPORT - DELIVERY } \\
\hline $\mathrm{M}$ & Expected daily need (pcs) & 600 & $E d n$ \\
\hline $\mathrm{M}$ & Expected monthly need (pcs) & 12000 & Emn \\
\hline $\mathrm{M}$ & Destination name & Koper-Lyon (F) & $D n$ \\
\hline $\mathrm{M}$ & Required transit time $(\mathrm{h})$ & 24 & $R t$ \\
\hline $\mathrm{M}$ & Expected monthly frequency - one way & 20 & Efo \\
\hline $\mathrm{M}$ & Expected monthly frequency - with return & 0 & Efr \\
\hline $\mathrm{M}$ & Type of transport & Road & $T t$ \\
\hline $\mathrm{M}$ & Vehicle capacity $(\mathrm{kg})$ & 24000 & $V_{c}$ \\
\hline $\mathrm{M}$ & Max. number of packaging on vehicle & 60 & $M p v$ \\
\hline $\mathrm{M}$ & One-way price $€$ & 1100,00 & Owp \\
\hline $\mathrm{M}$ & Price with return packaging $€$ & - & Prp \\
\hline $\mathrm{M}$ & Combination with other products (YES/NO) & YES & $K$ \\
\hline $\mathrm{C}$ & Transport costs per pcs $€$ & 0,041 & $T c$ \\
\hline \multicolumn{4}{|c|}{ TRANSPORT - GOODS FROM SUPPLIERS } \\
\hline $\mathrm{C}$ & Total costs of transport $€$ & - & $T c T$ \\
\hline $\mathrm{C}$ & Transport costs per pcs $€$ & - & $T c S$ \\
\hline \multicolumn{4}{|c|}{ WAREHOUSING - SELLING } \\
\hline $\mathrm{M}$ & Sum of gross personal income per month $€$ & 11525,00 & GpiS \\
\hline M & $\begin{array}{l}\text { Average number of processed } \\
\text { packaging per hour }\end{array}$ & 40 & $A P p S / \mathrm{h}$ \\
\hline $\mathrm{M}$ & Fork-lift purchase values $€$ & 60000,00 & Flv \\
\hline $\mathrm{M}$ & Number of fork-lifts & 4 & $N f$ \\
\hline $\mathrm{M}$ & Amortization period of fork-lifts (years) & 5 & $A m P$ \\
\hline $\mathrm{M}$ & Number of working days (on year basis) & 250 & $W k / d$ \\
\hline $\mathrm{M}$ & Number of working hours & 8 & $W k / \mathrm{h}$ \\
\hline $\mathrm{C}$ & Fork-lift costs $(€ / \mathrm{pcs})$ & 0,000 & $F l c / p$ \\
\hline $\mathrm{C}$ & Operational costs per pes & 0,000 & $O s c / \mathrm{p}$ \\
\hline $\mathrm{M}$ & Necessary storage space $\left(\mathrm{m}^{2}\right)$ & 1,06 & $N s S$ \\
\hline $\mathrm{M}$ & Lost warehouse rent $\left(€ / \mathrm{m}^{2}\right)$ & 8 & $L w r$ \\
\hline $\mathrm{C}$ & Warehouse space costs (€/pal.) & 0,000 & $W s c S$ \\
\hline $\mathrm{C}$ & Warehouse space costs (€/pcs) & 0,000 & $W s c S / \mathrm{p}$ \\
\hline $\mathrm{C}$ & Internal warehousing costs $(€ / \mathrm{pcs})$ & 0,018 & $I w c S / \mathrm{p}$ \\
\hline $\mathrm{C}$ & External warehousing costs (€/pal.) & 14,2 & $E w c S$ \\
\hline $\mathrm{C}$ & External warehousing costs $(€ /$ pcs $)$ & 0,072 & $E w c S / \mathrm{p}$ \\
\hline $\mathrm{C}$ & Total warehousing cost - selling $€ / \mathrm{pcs}$ & 0,090 & $W_{c} S$ \\
\hline \multicolumn{4}{|c|}{ WAREHOUSING - PURCHASING } \\
\hline $\mathrm{M}$ & Sum of gross personal income per month $€$ & 7560,00 & GpiP \\
\hline M & Num. of units for manipulation & 8 & $U m$ \\
\hline $\mathrm{M}$ & Necessary storage space $\left(\mathrm{m}^{2}\right)$ & 1,78 & $N S S$ \\
\hline $\mathrm{M}$ & Lost warehouse rent $\left(€ / \mathrm{m}^{2}\right)$ & 8 & $L w r$ \\
\hline $\mathrm{M}$ & Average number of processed packaging per hour & 60 & $A P p P / \mathrm{h}$ \\
\hline $\mathrm{C}$ & Warehouse space costs $(€ /$ pal. $)$ & - & $W s c P$ \\
\hline $\mathrm{C}$ & Warehouse space costs $(€ / \mathrm{pcs})$ & - & $W s c P / \mathrm{p}$ \\
\hline $\mathrm{C}$ & Internal warehousing costs $(€ / \mathrm{pcs})$ & 0,018 & $I w c P / \mathrm{p}$ \\
\hline
\end{tabular}




\begin{tabular}{|c|c|c|c|}
\hline $\mathrm{C}$ & External warehousing costs (€/pal.) & - & $E w c P$ \\
\hline $\mathrm{C}$ & External warehousing costs (€/pcs) & - & $E w c P / \mathrm{p}$ \\
\hline $\mathrm{C}$ & Total warehousing cost - purchasing $€ /$ pcs & 0,018 & $W_{c} P$ \\
\hline \multicolumn{4}{|c|}{ CAPITAL IN STOCKS } \\
\hline M & Value delivery lot $€$ & 1366,20 & $V$ \\
\hline $\mathrm{M}$ & Interest & $5,00 \%$ & $I$ \\
\hline $\mathrm{M}$ & Term of payment - purchasing (days) & 60 & $T p P$ \\
\hline $\mathrm{M}$ & Inventory turn & 12 & It \\
\hline $\mathrm{M}$ & Term of payment - sales (days) & 90 & $T p S$ \\
\hline $\mathrm{C}$ & Capital costs in stocks $€$ & 0 & $C c S$ \\
\hline $\mathrm{C}$ & Capital costs $€ /$ pcs & 0 & $C c$ \\
\hline \multicolumn{4}{|c|}{ OTHER LOGISTICS COSTS } \\
\hline $\mathrm{C}$ & Other logistics costs $€ / \mathrm{pcs}$ & 0 & Olc \\
\hline $\mathrm{C}$ & Other logistics costs $€ /$ pcs & 0 & Olc \\
\hline \multicolumn{2}{|r|}{ Total logistics costs of the product $€$} & 0,160 & $T l c P$ \\
\hline
\end{tabular}

\section{Testing the proposed model on a product made by a manufacturing company}

Based on the collected data, we have tested the proposed model on the product hinge G9. Every piece of data entered into the model affects the structure of the total logistics costs associated with a specific product $(T l c P)$, which the user can directly determine when performing a test of the model. The basic formula of the model is as follows:

$T l c P=P c+T c+T c S+W c S+W c P+C c$.

Where:

TlcP - total logistics cost of the product,

$P c$ - packaging cost,

$T c$ - transport cost - delivery,

$T c S$ - transport cost from suppliers,

$W c S$ - total warehousing cost - selling,

$W c P$ - total warehousing cost - purchasing,

$C c$ - capital cost.

Basic data entry requires the user to enter the net weight of the product, the expected product life cycle, the price minus the logistics costs, the weight of the packaging unit and the number of pieces in the packaging unit. Then, the model provides the calculation of the nonreturnable packaging cost $(N r p C p)$ and the returnable packaging cost $(R p C p)$ per piece. The final calculation tells us which logistics option is the most cost-effective in terms of packaging.

$$
\begin{aligned}
& N p u=\frac{E d n}{N p}, \\
& N r p c=P c M \cdot N p u, \\
& N r p c / \mathrm{p}=\frac{E r p c}{E d n} .
\end{aligned}
$$

Where:

Nrpc - not returnable packaging cost,

$P c M$ - packaging cost per pallet $€$ (material),

$N p u$ - number of packaging units for order,

$N p$ - number of pieces in packaging unit,

$\mathrm{Nrpc} / \mathrm{p}$ - not returnable packaging cost per pcs,

$E d n$ - expected daily need (pcs).

Calculation:

$$
\begin{aligned}
& N p u=\frac{600 \mathrm{pcs}}{196 \mathrm{pcs}}=3,06=4 \text { units for order } \\
& N r p c=1,7 € \times 4 \text { units }=6,8 € \\
& N r p c / \mathrm{p}=\frac{6,8 €}{600 \mathrm{pcs}}=0,011 € / \mathrm{pcs}
\end{aligned}
$$

Returnable packaging cost:

$$
\begin{aligned}
& N s=E f o+E f r, \\
& N u r p=\frac{E d n}{N p} \times N s+P s, \\
& V r p=P u c \times N u r p, \\
& N p P l c=P l c \times E d n \times N s \times 12 \text { months, } \\
& R p C p=\frac{V r p}{N p P l c}, \\
& P c=N r p C p \text { or } R p C p .
\end{aligned}
$$

Where:

Nurp - number of returnable packaging in circulation,

$E d n$ - expected daily need (pcs),

$\mathrm{Np}$ - number of pieces,

$N s$ - number of shipments,

$P s$ - packaging stock,

$V r p$ - value of returnable packaging,

$P u c$ - packaging unit cost,

$\mathrm{NpPlc}$ - number of pcs in the product life cycle,

$P l c$ - product life cycle,

$R p C p$ - returnable packaging cost per pcs,

Efo - expected monthly frequency - one way,

$E f r$ - expected monthly frequency - with return.

The company uses non-returnable packaging, so we created a simulation that takes into account the use of returnable packaging. The purpose was to determine whether it would be advisable in terms of the costs to change the logistics of the packaging.

Calculation:

$$
\begin{aligned}
& N s=20 \text { shipments } \\
& N u r p=\frac{600 \mathrm{pcs}}{196 \mathrm{pcs}} \times 20+5=67 \text { pallets } \\
& V r p=200,00 € \times 67 \text { pallets }=13400,00 € \\
& N p P l c=6 \times 600 \mathrm{pcs} \times 20 \times 12=864000 \mathrm{pcs}
\end{aligned}
$$




$$
R p C p=\frac{13400 €}{864000 \mathrm{pcs}}=0,0155 € / \mathrm{pcs}
$$

In order to calculate the transport costs per item, we need to know the weight of each order (Weo). If the company delivers the product hinge G9 to the same destination as its other products, we take into account the optimal loading of the transport vehicle to calculate the optimal transport price, based on the relative weight of the goods delivered.

$$
\begin{aligned}
& \text { Weo }=N w p \times E d n+W p \times N p u, \\
& O t p=\frac{O w p}{V c} \times W e o, \\
& O t p / \mathrm{p}=\frac{O t p}{E d n}
\end{aligned}
$$

If the delivery of the goods is not combined with the delivery of other products, we calculate the price of transport for the goods separately:

$$
R t p / \mathrm{p}=\frac{O w p}{W e o} .
$$

Where:

Otp - optimal transport price

Otp/p - optimal transport price per pcs

$R t p / \mathrm{p}$ - regular transport price per pcs

Owp - one-way price

$V c$ - vehicle type (capacity) $(\mathrm{kg})$

Weo - weight of each order $(\mathrm{kg})$

$N w p$ - net weight of product $(\mathrm{kg})$

$W p$ - weight of packaging $(\mathrm{kg})$

$N p$ - number of pieces

$\mathrm{Npu}$ - number of packaging units per order

$E d n$ - expected daily need (pcs)

Calculation:

$$
\begin{aligned}
& \text { Weo }=0,632 \mathrm{~kg} \times 600 \mathrm{pcs}+36 \mathrm{~kg} \times 4 \text { units }=523,20 \mathrm{~kg}(23) \\
& \text { Otp }=\frac{1100 €}{24000 \mathrm{~kg}} \times 523,20 \mathrm{~kg}=23,98 € \text { if there are no returns }(24) \\
& \text { Otp } / \mathrm{p}=\frac{23,98 €}{600 \mathrm{pcs}}=0,0399 € / \mathrm{pcs}
\end{aligned}
$$

The average price is calculated if the responsibility for the acceptance of returnable packaging is defined. This item is often ignored. Since the company delivers products with non-returnable packaging and we were only given the price for one-way transport, the calculation is merely a suggestion.

$$
\begin{aligned}
& A p=\frac{O w p \times E f o+P r p \times E f r}{N s}, \\
& O t p=\frac{A p}{V t c} \times W e o, \\
& A p / \mathrm{p}=\frac{A p}{E d n},
\end{aligned}
$$

$T c=O t p / \mathrm{p}$ or $R t p / \mathrm{p}$ or $A p / \mathrm{p}$.

In this case, the mode of transport is $O t p / p$ therefore Tc equals $0,0399 € / \mathrm{pcs}$.

Where:

$A p$ - average price,

$A p / \mathrm{p}$ - average price per pcs,

$O w p$ - one-way price,

$E f o$ - expected monthly frequency - one way,

Efr - expected monthly frequency - with return,

Prp - price with return packaging,

$N s$ - number of shipments,

$T c$ - transport cost,

$E d n$ - expected daily need (pcs).

If the company covers the cost of transport from the suppliers, the calculation is as follows:

$T c s=\frac{T c T}{E d n}$

Where:

$T c t$ - total costs of transport from suppliers,

$T c s$ - transport cost from suppliers.

This is where we calculate the costs of warehousing that are directly related to the final product or to the shipment of goods to the buyer.

$$
\begin{aligned}
A F l v & =\frac{F l v}{N f}, \\
F l v c / \mathrm{h} & =\frac{A F l v}{A m P \times W k / \mathrm{d} \times W k / \mathrm{h}}, \\
F l c / \mathrm{p} & =\frac{N p u}{A P p S / \mathrm{h}} \times \frac{F l c / \mathrm{h}}{E d n}, \\
O s c / \mathrm{h} & =\frac{G p i S}{W k / \mathrm{d} \times W k / \mathrm{h}}, \\
O s c / \mathrm{p} & =\frac{N p u}{A P p S / \mathrm{h}} \times \frac{O s c / \mathrm{h}}{E d n}, \\
W s c S & =L w r \times N s s, \\
W s c S / \mathrm{p} & =\frac{W s c S}{E m n} .
\end{aligned}
$$

If the company is using a rented (external) warehouse, we use the following formula:

$$
E w c S / \mathrm{p}=\frac{E w c S \times N p u}{E d n}
$$

The warehousing costs - selling are as follows:

$W c S=F l c / p+O s c / p+W s c S / \mathrm{p}+E w c S / \mathrm{p}$

where:

$A F l v$ - average forklift purchase value,

$N f$ - number of fork-lifts,

$F l v$ - forklift purchase values, 
$F l c /$ h - fork-lift costs per hour,

AmP - amortization period (years),

$W k / \mathrm{d}$ - number of working days,

$W k / \mathrm{h}$ - number of working hours,

$N h f$ - number of hours of daily forklift use,

$F l c / p$ - forklift costs per pcs,

$\mathrm{Npu}$ - number of packaging units for order,

$A P p S / \mathrm{h}$ - average number of processed packaging per hour (selling),

$\mathrm{Flc} / \mathrm{h}$ - forklift costs per hour,

$E d n$ - expected daily need (pcs),

Emn - expected monthly need (pcs),

$O s c / \mathrm{h}$ - operational staff costs per hour,

GpiS - gross personal income per month - selling,

$N w s$ - number of warehouse staff,

$O s c / p$ - operational staff costs per pcs,

$W s c S$ - warehouse space costs per pallet - selling,

$W s c S / p$ - warehouse space costs per pcs - selling,

EwcS/p - external warehousing costs per pcs - selling,

$E w c S$ - external warehousing costs per pallet - selling,

$L w r$ - lost warehouse rent,

$N s S$ - necessary storage space,

$W c S$ - total warehousing cost - selling.

Calculation:

$$
\begin{aligned}
& A F l v=\frac{60000,00 €}{4}=15000,00 € \\
& F l c / \mathrm{h}=\frac{15000,00 €}{5 \text { years } \times 250 \text { days } \times 8 \mathrm{~h}}=1,5 € / \mathrm{h} \\
& F l c / \mathrm{p}=\frac{4 \text { pallet }}{40 \text { pallet }} \times \frac{1,5 € / \mathrm{h}}{600 \mathrm{pcs}}=0,00025 € / \mathrm{pcs} \\
& O s c / \mathrm{h}=\frac{11525,00 €}{250 \text { days } \times 8 \mathrm{~h}}=5,76 € / \mathrm{h} \\
& O s c / \mathrm{p}=\frac{4 \text { pallet }}{40 \text { pallet }} \times \frac{5,7625 € / \mathrm{h}}{600 \mathrm{pcs}}=0,00096 € / \mathrm{pcs} \\
& W s c S=8,00 € \times 1,06 \mathrm{~m}^{2}=8,48 € \\
& W s c S / \mathrm{p}=\frac{8,48 €}{12000}=0,0007 € / \mathrm{pcs} \\
& E w c / \mathrm{p}=\frac{14,2 € \times 4 \mathrm{pallet}}{600 \mathrm{pcs}}=0,0946 € / \mathrm{pcs} \\
& W c S=0,09651 € / \mathrm{pcs}
\end{aligned}
$$

In this section we calculate the warehousing cost purchasing.

$$
\begin{aligned}
& F l c / \mathrm{p}=\frac{U m}{A P p P / \mathrm{h}} \times \frac{F l c / \mathrm{h}}{E d n}, \\
& O s c / \mathrm{h}=\frac{G p i P}{W k / \mathrm{d} \times W k / \mathrm{h}}, \\
& O s c / \mathrm{p}=\frac{U m}{A P p P / \mathrm{h}} \times \frac{O s c / \mathrm{h}}{E d n}, \\
& W s c P=L w r \times N s s, \\
& W s c P / \mathrm{p}=\frac{W s c P}{E m n} .
\end{aligned}
$$

If the company is using a rented (external) warehouse, we use the following formula:

$E w c P / \mathrm{p}=\frac{E w c P \times U m}{E d n}$,

$W c P=F l c / \mathrm{p}+O s c / \mathrm{p}+E w c P / \mathrm{p}+W s c P / \mathrm{p}$,

where:

$A P p P / \mathrm{h}$ - average number of processed packaging per hour (purchasing),

$U m$ - number of units for manipulation,

GpiP - gross personal income per month - purchasing,

$W s c P$ - warehouse space costs per pallet - purchasing,

$W s c P / \mathrm{p}$ - warehouse space costs per pcs - purchasing,

$N S S$ - necessary storage space - purchasing,

$L w r P$ - lost warehouse rent - purchasing,

$E w c P / p$ - external warehousing costs per pcs - purchasing, $E w c P$ - external warehousing costs per pallet- purchasing, $W c P$ - total warehousing cost - purchasing.

Calculation:

$F l c / \mathrm{p}=\frac{8 \text { pallet }}{60 \text { pallet }} \times \frac{1,5 € / \mathrm{h}}{600 \mathrm{pcs}}=0,00032 € / \mathrm{pcs}$

$O s c / \mathrm{h}=\frac{7560,00 €}{250 \text { days } \times 8 \mathrm{~h}}=3,78 € / \mathrm{h}$

Osc $/ \mathrm{p}=\frac{8 \text { pallet }}{60 \text { pallet }} \times \frac{3,78 € / \mathrm{h}}{600 \mathrm{pcs}}=0,00082 € / \mathrm{pcs}$

$W s c P=8,00 € \times 1,78 \mathrm{~m}^{2}=14,24 €$

$W s c P / \mathrm{p}=\frac{14,24 €}{12000}=0,0012 € / \mathrm{pcs}$

$W c P=0,00032 €+0,00082 €+0,0012 €=0,0023 € / \operatorname{pcs}(61)$ [17]):

The cost of capital in stocks is calculated as follows

$$
\begin{aligned}
& I t d=\frac{365 \text { days }}{I t}, \\
& C c S=\frac{I t d+T p S-T p P}{365 \text { days }} \times V \times I, \\
& C c=\frac{C c S}{E d n} .
\end{aligned}
$$

Where:

$C c S$ - capital cost in stocks,

It - inventory turn,

Itd - inventory turn - days of availability,

$T p P$ - term of payment in purchasing,

$T p S$ - term of payment in sales,

$V$ - value of delivery lot,

$I$ - interest.

Calculation:

$I t d=\frac{365 \text { days }}{12}=30,41$ days 


$$
\begin{aligned}
& C c S=0,1655 \times 1366,20 € \times 5,00 \%=11,30 € \\
& C c=\frac{11,30 €}{600 \mathrm{pcs}}=0,0188 € / \mathrm{pcs} .
\end{aligned}
$$

The model's final formula combines the cost of packaging $(P c)$, transport costs - distribution $(T c)$, transport costs - of the products from the suppliers (TcS), warehousing costs - selling $(W c S)$, warehousing costs purchasing $(W c P)$ and the cost of capital $(C c)$ into a single criterion for controlling the logistics costs of the company. According to the tested model, the total logistics costs for the product hinge G9, amount to:

$$
\begin{aligned}
& T l c P=0,011+0,0399+0,09651+0,0023+0,0188 \\
& T l c P=0,1685 € / \mathrm{pcs}
\end{aligned}
$$

\section{Discussion}

Based on the results of the test conducted on the product hinge G9 using the proposed model, the logistics costs are 5,3\% higher than the existing costs. According to the company, the total logistics costs for the aforementioned product are $0,16 €$, while the results of the test have shown that the total logistics costs amount to $0,1685 €$. The information related to the different types of logistics costs is also relevant. The cost of a returnable packaging unit was the same in both cases, amounting to $0,011 € /$ piece. The company has not provided any data on the cost of returnable packaging. Therefore, we have conducted a simulation using the model and the results indicated a higher cost, which amounts to $0,0155 € / \mathrm{pc}$.

The use of returnable packaging is therefore warranted. The cost of transport in the delivery of goods to customers is higher by $0,0011 € / p c(2,7 \%)$ in the company. The transport costs for the supplying of the goods were not calculated because in this case the suppliers organize the transport.

The company uses both its own and external warehousing facilities for the distribution of goods. The company does not account separately for the forklift cost, the operational staff cost and the warehouse space cost for each individual product, but only the cost of internal warehousing, which amounts to $0,018 € /$ piece.

Through the proposed model, we were able to calculate these items and obtain the following results: forklift cost - 0,00025 €/piece, operational staff cost $0,00096 € /$ piece and warehouse space cost $-0,0007 € /$ pc.

When we calculated the cost of external warehousing using the model, the value obtained was higher than that obtained by the company $(0,0946 € /$ piece $)$, because we took into account the expected daily need (pcs) and the required number of packaging units per order. According to the company, the cost amounted to $0,072 € /$ piece $(14,2$ $€$ per pallet, divided by the 196 pieces in a pallet). The total warehousing cost - selling amounts to 0,09651 $€ /$ piece.

The company uses its own warehouse facilities to store purchased goods, the cost of which amounts to $0,018 € /$ piece. In this case, we were also able to calculate the following: forklift cost - 0,00032 $€$ /piece, operational staff cost - 0,00082 €/piece and warehouse space cost -
$0,0012 € /$ piece (totalling $0,0023 € /$ piece). The company does not calculate the cost of capital in stocks. Using this model, we were able to determine that the cost of capital in stocks amounts to $0,0188 € / \mathrm{pc}$.

\subsection{Practical implications on logistics}

The use of the model enables close cooperation among the employees of the company, since all the departments involved in the logistical process are also involved in the process of managing logistics costs. This enables us to control logistics costs more effectively, as well as to organize the logistics system of the company in a more effective manner. This allows all employees, whose decisions affect the level of logistics costs, but who lack adequate knowledge of logistics, to be included in the logistics decision-making process. The test of the proposed model on the product hinge G9 yielded the following results:

- Applicability of the model to a practical example (calculation of the total logistics costs of the product in the company)

- Separate calculations of the individual logistics costs (the cost of capital in stocks, the forklift cost, the operating staff cost, the cost of using the company's own warehouse facilities, the cost of returnable packaging), resulting in better quality logistics costs data,

- The option of simulating different decision-making scenarios, which allow the participation of employees from different levels within the organization (corporate executives, middle management, operational staff) and from different business functions (sales, purchasing, logistics, production, marketing, etc.).

The SLDM results pose a number of questions to the users in a company, which allow them to analyse logistics costs from the strategic, tactical and operational decisionmaking perspective, making it much easier to choose the most adequate and effective strategy for the management of logistics costs.

\section{Strategic questions:}

1. How do different levels of customer service affect the level of logistics costs?

- The increased level of customer service in connection to the product hinge G9 results in a higher cost of capital in stocks (long payment terms in sales - 90 days) and affects the use of external warehousing. The cost of packaging, transport, and internal warehousing are not affected.

2. What are our payment terms and how do they affect the cost of capital in stocks?

- The payment terms for the tested product are not consistent, namely they are short in the process of buying and long in the process of selling. The imbalance between payment terms directly affects the cost of capital in stocks, which amounts to $11,30 €$ for each shipment. If payment terms in selling and purchasing were the same (90 days), the cost of capital in stocks for each shipment would decrease to $5,69 €$. 
3. To what extent are we financing the buyers?

For each shipment, our financing of the buyers amounts to $5,61 €$. In selling, the payment period is 30 days longer than it is in purchasing and the aforementioned amount corresponds to the difference in price, if the payment period in purchasing was also 90 days.

4. To what extent are we financed by the suppliers?

- We are not financed by the suppliers, because they have shorter payment periods.

5. What is the share of individual logistics costs in the product price?

- The highest cost is that of warehousing - selling $(4,23$ $\%$ ), followed by transport $(1,75 \%)$, the cost of capital in stocks $(0,82 \%)$, packaging $(0,48 \%)$ and warehousing - buying $(0,1 \%)$.

6. Which of our products (per customer) have the lowest logistics costs and which have the highest?

- In the case of the product hinge G9, the share of logistics costs in the price of the product is $7,4 \%$, which equals $0,1685 €$ per piece.

7. Have we chosen the right approach for the distribution of the product?

- In the distribution of the product, our warehousing costs are higher because we are using external storage facilities. Combining shipping with other products brings the cost of transport to an optimal level. This approach allows us to better serve the needs of the customer when delivering the goods.

8. Which departments in the company most affect the level of logistics costs?

The sales department has the greatest impact on logistics costs, due to warehousing costs - selling $(4,23 \%)$, transport $(1,75 \%)$ and the cost of capital in stocks $(0,82 \%)$. The impact of the sales department on the amount of logistics costs is $81 \%$.

\section{Tactical and operational questions:}

9. What are the costs of returnable and non-returnable packaging?

- The cost of non-returnable packaging amounts to $0,011 € /$ piece. If the company switched to returnable packaging, it would drop to $0,0155 € / \mathrm{pc}$.

10. What mode of transport guarantees the lowest logistics costs?

- The delivery of the product hinge G9 is combined with the delivery of other products. This method of delivery ensures that transport costs are kept at a minimum.

11. What method of warehousing ensures the lowest logistics costs?

- By using the company's own warehouse, logistics costs are kept at a minimum, because there is no need to rent an additional external warehouse.

12. What are our payment terms in purchasing and how do they affect the cost of capital in stocks?

- In the purchasing of goods, the payment period is 60 days, which has a negative impact on the cost of capital in stocks.

13. What are our payment terms in selling and how do they affect the cost of capital in stocks?

- In the selling of goods, the payment period is 90 days, which has a negative impact on the cost of capital in stocks, since the payment period is longer than purchasing period.

14. Which method of packaging management results in the lowest logistics costs?

- The current use of non-returnable packaging results in the lowest logistics costs.

15. How does inventory turnover affect logistics costs?

- Inventory turnover for the product hinge G9 is 12 times a year or every 30 days (the cost per shipment is $11,30 €$ - i.e., $0,0188 €$ per piece. Inventory turnover does not positively affect logistics costs. If inventory were turned over once a week ( 52 times per year), the cost per shipment would be $6,92 €$ - i.e., $0,011 €$ per piece.

\subsection{Contribution to theory}

The questions also help define the contribution of the proposed methodology to theory, because the process of understanding the controlling of logistics costs is simplified and accessible to a wider range of users (researchers, IT professionals and users in companies).

The model requires the user to enter data from an early stage, which forces the user to think about controlling logistics costs and organizing the logistics process of the company, using a systemic approach. Any reduction or increase in a certain parameter affects the final price of the product, which can be determined by the user directly through a change in the input in the formula:

$T l c P=P c+T c+T c S+W c S+W c P+C c$.

By using the model, employees from different hierarchical levels and from different business functions can be involved in the decision-making process of controlling logistics costs. The answers to the aforementioned logistical questions offer the possibility of simulating different decision-making scenarios and enable the participation of employees who, through the transfer of their knowledge and experience, contribute significantly to the company's logistics intellectual capital. This creates a process of organizing the basic principles of knowledge creation, which will be useful to the company in the long run.

\subsection{The weaknesses and risks connected with the implementation of the proposed mode}

The paper proposes a new methodology that requires further testing in different companies and on different products. Although the new model provides many benefits, the fact remains that it would be impossible to create a model that would allow us to control all the logistics costs during a product's life cycle, because some logistics costs are difficult to define precisely. Such costs include IT system costs, operational staff costs in other departments dealing with logistics and various fixed and variable costs associated with the use of equipment during the storage and transport of goods.

In addition, there is no way to ensure that the data entered is correct, affecting the way logistics costs are calculated and therefore potentially leading to wrong decisions. Thus, it would be advisable to identify the key 
users of the model for each business area in the company who will be responsible for entering the data, or to organize employee-training courses on data entry and the use of the model. The successful operation of the logistics model also depends on the introduction of modern managerial cost control methods, which may affect the mindset of the employees and their commitment to controlling the logistics costs in the company.

The model is designed for the calculation of logistics costs for an individual product. Therefore, calculating the logistics costs of more than one product would require us to formulate and build an information platform that would cover all the products that are part of a company's range of products.

\section{Conclusion and guidelines for future research}

Companies that do not list logistics among their primary activities are adversely affected by their lack of knowledge in the field of logistics processes and systemic control of logistics costs. A lack of awareness of the interdependence of logistics costs exposes the potential contradictions of individual interests of individual departments within a company, which are not always in line with the common interests of the business process of a company. Some limitations are also apparent, if we analyse the applicability of logistics cost models. Such models generally deal with areas that require the adoption of long-term objectives and actions that are defined by strategic decisions, and to a lesser extent, tactical ones.

Employees at lower levels of the organizational hierarchy who make operational decisions that must also be supported by adequate decision-making tools, are excluded from this decision-making process. A second limitation relates to the applicability of logistics models in practice, since logistics cost models have developed beyond what would be considered user-friendly by potential users in companies. The logistics cost models examined introduce important mathematical solutions in terms of solving complex logistical problems. However, the knowledge delivered by the development of various heuristic approaches and algorithmic structured models is accessible and useful to a small circle of experts. This knowledge is less accessible to ordinary users who work in companies and want to find out how their decisions affect the quality of the logistics process and the overall logistics costs for a given product. The purpose of our research was to create a generally applicable model which merges the decision-making process into a single criterion of strategic, tactical and operational decision making. The Systematic Logistics Decision-Making Model (SLDM) is easy to use and is available to employees at different hierarchical levels within organizations and for different business functions, with the purpose of managing the total logistics costs of the company.

The results of testing the proposed methodology on the product hinge G9 delivered significant results that will affect the area of controlling logistics costs both in theory and in practice. The SLDM covers the total logistics costs incurred by a company and, as demonstrated, the model is applicable in practice. The use of the model improves the quality of the information obtained, since it includes several types of logistics costs that were not included in the calculations made by the company. The model examines the entire logistics system of a company, since it accounts for the costs of returnable and non-returnable packaging, transport costs incurred during the selling and purchasing of goods, warehousing costs incurred during the selling and purchasing of goods and the cost of capital in stocks. The results of the model provide answers to various logistics questions, enabling us to achieve greater control over logistics costs, improve employee participation in the process of controlling logistics costs, allowing us to better organise the logistics process and to choose the most suitable strategy for controlling logistics costs. This allows all the employees, whose decisions affect the level of logistics costs but who lack adequate knowledge on logistics, to be included in the logistics decision-making process.

The paper proposes a new methodology for controlling logistics costs. Additional testing in different companies and on different products is required in order to achieve improvements in terms of the calculation of the types of logistics costs that were not included in the testing of the applicability of the model on the product hinge G9. The model is designed to calculate the logistics costs for an individual product; thus future research should be geared towards determining the possibilities for integrating the model into a single managerial information system which would cover all the products that are produced by a company.

\section{References}

[1] Ali, A. I.; O'Connor, D. J. Using Truck-Inventory-Cost to Obtain Solutions to Multi-Period Logistics Models. // International Journal of Production Economics. 143, 1(2013), pp. 144-150. DOI: 10.1016/j.jpe.2012.12.022

[2] Argote, L.; Ingram, P. Knowledge Transfer: A Basis for Competitive Advantage in Firms. // Organizational Behavior and Human Decision Processes. 82, 1(2000), pp. 150-169. DOI: 10.1006/obhd.2000.2893

[3] Bartolacci, M. R.; LeBlanc, L. J.; Kayikci, Y.; Grossman, T. A. Optimization Modeling for Logistics: Options and Implementations. // Journal of Business Logistics. 33, 2(2012), pp. 118-127. DOI: 10.1111/j.0000-0000.2012.01044.x

[4] Berman, O.; Wang, Q. Inbound Logistic Planning: Minimizing Transportation and Inventory Cost. // Transportation Science. 40, 3(2006), pp. 287-299. DOI: $10.1287 /$ trsc. 1050.0130

[5] Bertazzi, L.; Speranza, M. G.; Ukovich, W. Minimization of Logistics Costs with Given Frequencies. // Transportation Research Part B Methodological. 31, 4(1997), pp. 327-340. DOI: 10.1016/S0191-2615(96)00029-X

[6] Bertazzi, L.; Speranza, M. G. Models and Algorithms for the Minimization of Inventory and Transportation Costs: A Survey. // Lecture Notes in Economics and Mathematical Systems. 480, (1999), pp. 137-157. DOI: 10.1007/978-3-64258568-5_7

[7] Blome, C.; Schoenherr, T.; Eckstein, D. The Impact of Knowledge Transfer and Complexity on Supply Chain Flexibility: A Knowledge-based View. // International Journal of Production Economics. 147 part B (2014), pp. 307-316.

[8] Blumenfeld, D. E.; Burns, L. D.; Diltz, J. D.; Daganzo, C. F. Analyzing Trade-Offs between Transportation, Inventory and Production Costs on Freight Networks. // Transportation Res. Part B. 19, 5(1985), pp. 361-380. DOl: 10.1016/0191-2615(85)90051-7 
[9] Blumenfeld, D. E.; Burns, L. D.; Daganzo, C. F.; Frick, M. C.; Hall, R. W. Reducing Logistics Costs at General Motors. // Interfaces. 17, 1(1987), pp. 26-37. DOl: 10.1287/inte.17.1.26

[10] Bošnjaković, M. Multicriteria inventory model for spare parts. // Tehnički vjesnik-Technical Gazette. 17, 4(2010), pp. 499-504.

[11] Bubeník, P.; Horák, F. Knowledge-based systems to support production planning. // Tehnički vjesnik-Technical Gazette. 21, 3(2014), pp. 505-509

[12] Burns, L. D.; Hall, R. W.; Blumenfeld, D. E.; Daganzo, C. F. Distribution Strategies that Minimize Transportation and Inventory Costs. // Operations Research. 33, 3(1985), pp. 469-490. DOI: 10.1287/opre.33.3.469

[13] Chow, G. A Total Logistics Cost Approach to Measuring Collateral Benefits of Security and Supply Chain Improvements at International Gateways. // Bureau of Intelligent Transportation Systems and Freight Security, Sauder School of Business. / University of British Columbia, Calgary Asia Pacific Gateway and Corridor Round Table. 2007, pp. 1-24.

[14] Estampe, D.; Lamouri, S.; Paris, J.; Brahim-Djelloul, S. A framework for analysing supply chain performance evaluation models. // Int. J. Production Economics. 142, 2(2013), pp. 247-258. DOI: 10.1016/j.jpe.2010.11.024

[15] Guerriero, F.; Musmanno, R.; Pisacane, O.; Rende, F. A Mathematical Model for the Multi-Levels Product Allocation Problem in a Warehouse with Compatibility Constraints. // Applied Mathematical Modelling. 37, (2013), pp. 4385-4398. DOI: 10.1016/j.apm.2012.09.015

[16] Gunasekaran, A.; Ngai, E. W. T. Decision Support Systems for Logistics and Supply Chain Management. // Decision Support Systems. 52, 4(2012), pp. 777-778. DOl: 10.1016/j.dss.2011.11.012

[17] Kivinen, P.; Lukka, A. Value-Added Logistical Support Service: Logistics Cost Structure and Performance in the New Concept, Part 3. // Department of Industrial Engineering and Management, Lappeenranta University of Technology, Finland / Lappeenranta, 2004, pp. 97.

[18] Lau, H. C. W.; Nakandala, D. A Pragmatic Stochastic Decision Model for Supporting Goods Trans-Shipments in a Supply Chain Management. // Decision Support Systems. 54, 1(2012), pp. 133-141. DOI: 10.1016/j.dss.2012.04.012

[19] Madadi, A.; Kurz, M.E.; Ashayeri, J. Multi-level Inventory Management Decisions with Transportation Cost Consideration. // Transportation Research Part E. 46, 5(2010), pp. 719-734. DOI: 10.1016/j.tre.2009.12.012

[20] Nam-Hong Yim; Soung-Hie Kim; Hee-Woong Kim; KeeYoung Kwahk. Knowledge-based Decision-Making on Higher Level Strategic Concerns: A System Dynamics Approach. // Expert Systems with Applications. 27, 1(2004), pp. 143-158. DOI: 10.1016/j.eswa.2003.12.019

[21] Pettersson, Annelie I.; Segerstedt, A. Measuring Supply Chain Cost. // International Journal of Production Economics. 143, 2(2013), pp. 357-363. DOI: 10.1016/j.ijpe.2012.03.012

[22] Robinson, T. Cost Modelling in the Integrated Supply Chain Strategic Decision Process. // Massachusetts Institute of Technology, Department of Mechanical Engineering / Sloan School of Management, 2006, pp. 61.

[23] Sajadieh, M. S.; Thorstenson A.; Akbari Jokar M. R. An Integrated Vendor-Buyer Model with Stock-Dependent Demand. // Transportation Research Part E: Logistics and Transportation Review. 46, 6(2010), pp. 963-974. DOI: 10.1016/j.tre.2010.01.007

[24] Speranza, M. G.; W. Ukovich. Minimizing Transportation and Inventory Costs for Several Products on a Single Link. // Operations Research. 42, 5(1994), pp. 879-894. DOl: 10.1287/opre.42.5.879
[25] Stapleton, D.; Hanna, J. B.; Yagla, S.; Johnson, J.; Markussen, D. Measuring Logistics Performance Using the Strategic Profit Model. // International Journal of Logistics Management. 13, 1(2002), pp. 89-107. DOI: $10.1108 / 09574090210806388$

[26] Stock, J. R.; Lambert, D. M. Strategic Logistics Management, 4th ed., Boston [etc.] : McGraw-Hill : Irwin, 2001.

[27] Strack, G.; Pochet, Y. An Integrated Model for Warehouse and Inventory Planning. // Operational Research. 204, 1(2010), pp. 35-50. DOI: 10.1016/j.ejor.2009.09.006

[28] Tancrez, J. S.; Lange, J. C.; Semal, P. A Location-Inventory Model for Large, Three-Level Supply Chains. // Transportation Research Part E. 48, 2(2012), pp. 485-502. DOI: 10.1016/j.tre.2011.10.005

[29] Waller, M. A.; Fawcett, S. E. The Total Cost Concept of Logistics: One of Many Fundamental Logistics Concepts Begging for Answers. // Journal of Business Logistics. 33, 1(2012), pp. 1-3. DOI: 10.1111/j.0000-0000.2011.01033.x

[30] Wang, X.; Cheng, T. C. E. Logistics Scheduling to Minimize Inventory and Transport Costs. // International Journal of Production Economics. 121, 1(2009), pp. 266273. DOI: 10.1016/j.ijpe.2009.05.007

[31] Wheatley, M. J. The Real Work of Knowledge Management. // IHIRM Journal. 5, 2(2001), pp. 29-33.

[32] Zhao, Q. H.; Wang, S. Y.; Lai, K. K.; Xia, G. P. Model and Algorithm of an Inventory Problem with the Consideration of Transportation Cost. // Computers \& Industrial Engineering. $\quad 46, \quad 2(2004), \quad$ pp. 389-397. DOl: 10.1016/j.cie.2003.12.019

\section{Authors' addresses}

Sebastjan Skerlic, MSc.

Faculty of Maritime Studies and Transportation, University of Ljubljana, Pot pomorscakov 4, 6320 Portoroz, Slovenia E-mail: sebastjan.skerlic@fpp.uni-lj.si

\section{Robert Muha, PhD}

Faculty of Maritime Studies and Transportation, University of Ljubljana, Pot pomorscakov 4, 6320 Portoroz, Slovenia E-mail: robert.muha@fpp.uni-lj.si

Klavdij Logožar, PhD

Faculty of Economics and Business, University of Maribor, Razlagova 14, 2000 Maribor, Slovenia

E-mail: klavdij.logozar@uni-mb.si 